RITUAL IRONY 



\title{
RITUAL IRONY
}

\section{POETRY AND SACRIFICE IN EURIPIDES}

\author{
Helene P. Foley
}

Cornell University Press 
Open access edition funded by the National Endowment for the Humanities/Andrew W. Mellon Foundation Humanities Open Book Program.

Cornell University Press gratefully acknowledges a grant from the Andrew W. Mellon Foundation that aided in bringing this book to publication

\section{Copyright (C) 1985 by Cornell University}

First paperback printing 2019

The text of this book is licensed under a Creative Commons Attribution-NonCommercial-NoDerivatives 4.0 International License: https://creativecommons.org/licenses/by-nc-nd/4.0/.

To use this book, or parts of this book, in any way not covered by the license, please contact Cornell University Press, Sage House, 512 East State Street, Ithaca, New York 14850. Visit our website at cornellpress.cornell.edu.

Printed in the United States of America

ISBN 978-0-8014-1692-7 (cloth: alk. paper)

ISBN 978-1-5017-4062-6 (pbk.: alk. paper)

ISBN 978-1-5017-4063-3 (pdf)

ISBN 978-1-5017-4064-0 (epub/mobi)

Librarians: A CIP catalog record for this book is available from the Library of Congress

Jacket illustration: Sacrifice of Polyxena on an Attic Amphora, 550 B.C. Used by permission of the British Museum. 
To R. M. P. and D. K. F. 
